\title{
Syndrome of polyneuropathy, skin hyperpigmentation, oedema and hepatosplenomegaly
}

\author{
LOK-MING TANG, MO-SONG HSI, SHAN-JIN RYU, YASUHIRO MINAUCHI* \\ From the Department of Neurology, Chang Gung Memorial Hospital, Taiwan and the School of Medicine, \\ Kagoshima University, ${ }^{*}$ Japan
}

SUMMARY Four middle-aged male Chinese with polyneuropathy, skin hyperpigmentation, oedema, hepatosplenomegaly, ascites, gynaecomastia and white nails are described. In Japan and United States this syndrome has been associated with plasma cell dyscrasia. However, neither M-protein nor skeletal lesions were demonstrated in these four patients.

The occurrence of polyneuropathy in multiple myeloma is well documented. The presence of polyneuropathy with plasmacytoma was first reported by Scheinber in Austria, ${ }^{1}$ then by Crow in England. ${ }^{2}$ Thereafter, similar cases have been reported from various parts of the world. ${ }^{3-7}$ The syndrome of sensorimotor polyneuropathy, diffuse cutaneous hyperpigmentation, oedema, organomegaly, endocrinopathy and osteosclerotic myeloma were recorded by Japanese authors: Shimpo in $1968,{ }^{8}$ Shimomori and Kusumoto in $1970 .{ }^{9}$ The association of polyneuropathy with dysglobulinaemia, in which myeloma was not found haematologically, roentgenologically or pathologically, was reported by Iwashita et al in $1971 .^{10}$ The syndrome of multisystem involvement was reported to occur outside Japan by Trentham et al in $1976^{11}$ and Meshkinpour et al in 1977. ${ }^{2}$ In this report, we describe four Chinese patients with multisystem involvement without demonstrable myeloma.

\section{Case reports}

Case 1, a 40-year-old man was admitted in October 1979 because of progressive weakness of the lower extremities for three weeks. In the early spring of 1978, the patient became impotent. In May 1978, he found multiple nodules in both sides of the neck. In July 1979, aching pain and progressive numbness developed first in the big toes and then gradually extended up to the knee level. In September 1979 , the patient began to be numb in all his fingers and to be weak in his lower extremities. The family and the past

Address for reprint requests: Dr Lok-Ming Tang, Department of Neurology, Chang Gung Memorial Hospital, 199 Tung HWA North Road, Taipei, Taiwan, ROC.

Received 5 November 1982 and in revised form 10 March 1983. Accepted 27 March 1983 histories were unremarkable. He smoked five cigarettes a day and had not drunk alcohol for two years. There was no evidence of exposure to toxins or chemicals. Physical examination revealed dark colour of the skin and telangiectasia of the cheeks and nose. The fingernails and toenails were whitish. Bilateral gynaecomastia was present. Numerous soft lymph nodes were palpable in the neck (fig 1) and inguinal regions. There were hyperhidrosis and hypertrichosis of both legs. Weakness was present in the distal parts of the lower extremities. Deep tendon reflexes were absent in the limbs. There were hypalgesia and hypaesthesia, sometimes associated with dysaesthesia in the fingers and the lower extremities. Joint position sensation was preserved. Coordination and sphincter function were normal. Laboratory findings: WBC count was $7.63 \times$ $10 \% / 1$ with a normal differential cell count. Haemoglobin was $15.6 \mathrm{~g} / \mathrm{dl}$. Westergren sedimentation rate (ESR) was $45 \mathrm{~mm} / \mathrm{h}$. The fasting blood glucose level was $0.9 \mathrm{~g} / \mathrm{l}$. There was no Bence-Jones proteinuria. Serological tests for hepatitis and syphilis were negative. Tests for lupus erythematous (LE) cell, rheumatoid factor, cryoglobulin and cryofibrinogen were negative. The indirect immunofluorescent test for antinuclear antibody was negative. Third complement component (C3) level was 110 $\mathrm{mg} / \mathrm{dl}$. The result of radioimmunoassay for alphafoetoprotein was negative. Serum electrophoresis showed a total protein of $82 \mathrm{~g} / 11(63-80)$ and gamma-globulin of $30.4 \mathrm{~g} / \mathrm{l}(7-16)$. Immunoglobulin values and hormonal data are shown in table 2 and table 5 respectively. Cerebrospinal fluid (CSF) was clear and colourless with $270 \mathrm{mmH}_{2} \mathrm{O}$ initial pressure and $200 \mathrm{mmH}_{2} \mathrm{O}$ terminal pressure and the protein level was $0.27 \mathrm{~g} / \mathrm{l}$. CSF protein electrophoresis showed $33.05 \%$ (3-13) of gamma-globulin and CSF immunoassay revealed $0.095 \mathrm{~g} / 1(0.004-0.042)$ of IgG. Radiographs of the chest and the abdomen were normal as were gastric-intestinal radiographs and tomograms of the four limbs and the spine. Bone scan showed no abnormality. Liver biopsy, with amyloid stains, was normal. A bone marrow biopsy yielded $5 \%$ well-differentiated plasma cells without malignant cells. Biopsies of nasopharyngeal mucosa and neck lymph node revealed heavy infiltration of 


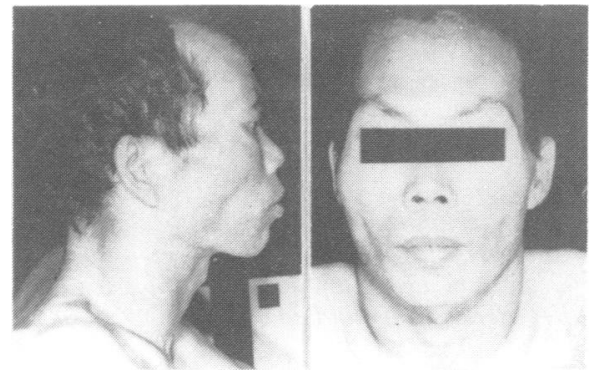

Fig 1 Enlarged lymph nodes in the neck of Case 1.

Table 1 Clinical manifestations of the four patients

\begin{tabular}{|c|c|c|c|c|}
\hline Findings & Case 1 & Case 2 & Case 3 & Case 4 \\
\hline Age (yr) of onset & 40 & 48 & 48 & 34 \\
\hline Sex & & & & \\
\hline Mode of onset & insidious & insidious & insidious & insidious \\
\hline $\begin{array}{l}\text { Polyneuropathy } \\
\text { Papilloedema }\end{array}$ & + & $\stackrel{+}{-}$ & $\begin{array}{l}+ \\
-\end{array}$ & + \\
\hline Darkening of the & & & & \\
\hline skin & + & + & + & + \\
\hline \multicolumn{5}{|l|}{ Thickening of the } \\
\hline skin & + & + & + & + \\
\hline Whitish nails & + & + & + & + \\
\hline Hypertrichosis & + & + & + & + \\
\hline Hyperhidrosis & + & $?$ & $?$ & $?$ \\
\hline $\begin{array}{l}\text { Gynaecomastia } \\
\text { Verrucose }\end{array}$ & + & + & + & + \\
\hline haemangioma & - & + & + & - \\
\hline \multicolumn{5}{|l|}{ Oedema of the } \\
\hline skin & + & + & + & + \\
\hline Ascites & + & + & + & + \\
\hline \multicolumn{5}{|l|}{ Hepatospleno- } \\
\hline $\begin{array}{c}\text { megaly } \\
\text { Lymphadenopathy }\end{array}$ & $\stackrel{+}{+}$ & $\stackrel{+}{-}$ & $\begin{array}{l}+ \\
+\end{array}$ & $\stackrel{t}{t}$ \\
\hline $\begin{array}{l}\text { Lymphadenopathy } \\
\text { Diarrhoea }\end{array}$ & $\begin{array}{l}+ \\
-\end{array}$ & $\bar{t}$ & $\stackrel{+}{-}$ & $\stackrel{+}{-}$ \\
\hline Impotence & + & + & $?$ & + \\
\hline
\end{tabular}

Table 2 Immunoglobulin values

\begin{tabular}{lcclll}
\hline & Case 1 & Case 2 & Case 3 & Case 4 & Normal Range \\
\hline IgG & 24.6 & $4 \cdot 44$ & 12.9 & $16 \cdot 8$ & $6 \cdot 0-15 \cdot 0 \mathrm{~g} / 1$ \\
IgM & $2 \cdot 2$ & $0 \cdot 5$ & $2 \cdot 72$ & $2 \cdot 8$ & $0 \cdot 35-2.0 \mathrm{~g} / 1$ \\
IgA & $4 \cdot 7$ & $1 \cdot 3$ & $2 \cdot 4$ & $4 \cdot 7$ & $0 \cdot 6-4 \cdot 5 \mathrm{~g} / 1$ \\
IgD & 66 & 27 & - & - & $<100 \mathrm{IU} / \mathrm{ml}$ \\
IgE & $<400$ & 940 & - & - & $<800 \mathrm{IU} / \mathrm{ml}$ \\
\hline
\end{tabular}

plasma cells (fig 2). Results of nerve stimulation studies are shown in table 4. Electromyography (EMG) of involved muscles showed fibrillation potentials and positive sharp waves at rest, polyphasic motor unit potentials with long duration on minimal effort and markedly reduced interference pattern on maximal effort. Sural nerve biopsy revealed segmental demyelination in $40 \%$ of the nerve fibres and axonal degeneration in $20 \%$ of the fibres (fig 3). There was reduction in the number of total myelinated fibres, especially the large fibres (fig 4). There were no inflammatory cells in the nerve fibre basement membrane. The non-myelinated fibres were almost intact.

The patient was treated with prednisolone $40 \mathrm{mg}$ daily in December 1979. The pain and the numbness in the limbs improved subjectively within two weeks. In January 1980 ,

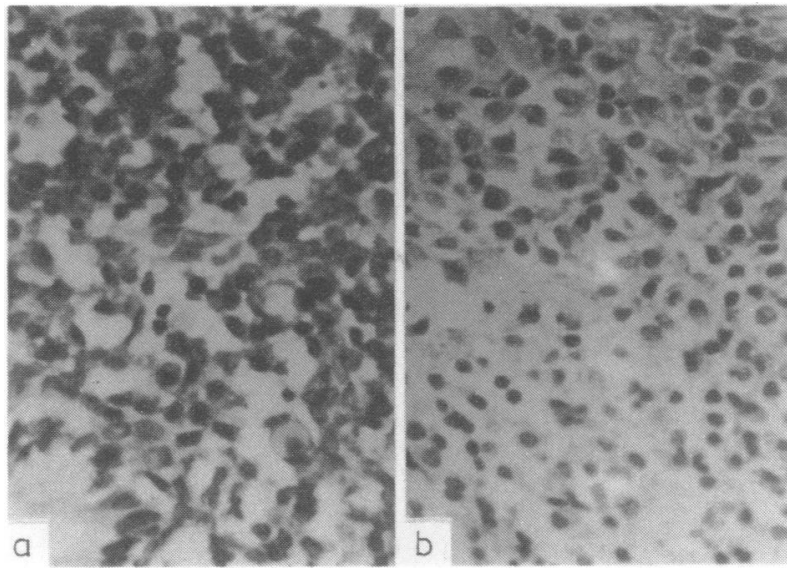

Fig 2 Findings of biopsies from nasopharyngeal mucosa (a) and neck lymph node (b) from Case 1: marked plasma cell inflitration $(H E$ stain; $\times 400)$.

there was relapse of numbness in the four limbs in spite of increasing the dosage of prednisolone to $80 \mathrm{mg}$ daily. Weakness became worse in the limbs and muscle wasting was noted. There were pitting oedema in the lower limbs and abdominal distension with shifting dullness. In December 1980, the patient experienced mild shortness of breath occasionally. Pulmonary function tests with spirometry detected severe non-obstructive ventilatory impairment. His skin became dry and lymph nodes of the neck became stony-hard. The liver and the spleen were enlarged. Opthalmoscopic examination revealed blurring of the disc margins which had been absent on the previous examinations (fig 5). In April 1981, the patient was readmitted because of the development of progressive hearing impairment in the right ear for 12 days. An audiogram revealed mixed type hearing loss and sensorineural hearing loss in the right and left ears respectively. Brain stem auditory evoked responses demonstrated the absolute wave I latency of $2.4 \mathrm{~ms}$ from the right ear and of $2.2 \mathrm{~ms}$ from the left ear with separate monaural stimulation at an intensity of $60 \mathrm{dBSL}$. The sequential deflections were poorly defined without definite prolongation of interpeak latencies. Electroencephalogram (EEG) and computed tomography (CT) of the brain showed no abnormality.

Case 2, a 48-year-old man was admitted in October 1979 for investigation of lower limb oedema for one month. The patient's past medical history had been unremarkable until July 1978 when he noticed several nodules ranging from $2 \mathrm{~mm}^{3}$ to $6 \mathrm{~mm}^{3}$ without discolouration over the chest and back. The nodules enlarged gradually over one month. In January 1979, the colour of the nodules became cherry red. In March 1979 , the patient had an attack of transient weakness of left arm and leg which lasted for about 15 minutes. Two weeks later, the attack of weakness of the limbs recurred and persisted. The weakness improved to the level that walking without support was possible within a month. In September 1979, the patient noticed intermittent pitting oedema of lower limbs and eyelids. There was also pallor of palms and fingernails. 

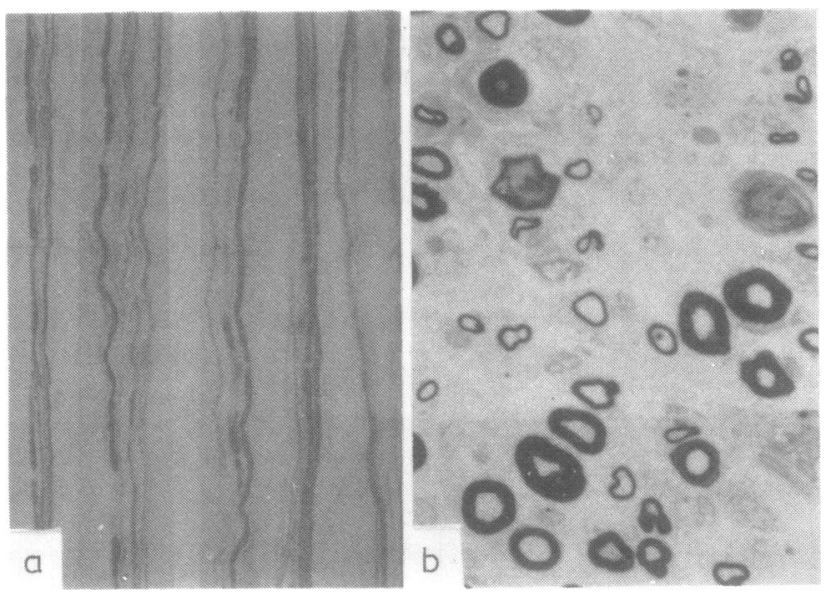

Fig 3 Findings of teased fibres (a) and transverse section (b) of sural nerve of Case 1: Segmental demyelination and axonal degeneration (Toluidine blue stain; $\times 500$ ).
Table 3 Percentage of plasma cells and eosinophils in bone marrow biopsy

\begin{tabular}{lllcl}
\hline & Case 1 & Case 2 & Case 3 & Case 4 \\
\hline Plasma cells (\%) & 5 & $1 \cdot 5$ & 6 & 10 \\
Eosinophils (\%) & 2 & 8 & 10 & 2 \\
\hline
\end{tabular}

He became impotent. The family history was unremarkable. There was no exposure to toxins or chemicals. On admission, physical examination revealed pale conjunctivas, hyperpigmentation of the skin, whitish fingernails and toenails, pitting oedema of both legs, abdominal distension, and multiple cherry red nodules ranging from a few $\mathrm{mm}$ to $13 \mathrm{~mm}$ in diameter over the chest and the back. There was hypertrichosis of the legs. No lymph nodes were palpable. There was upper motor neuron weakness of the left arm, leg and face. Deep tendon reflexes were hyperactive in the left limbs. Sensation to pinprick and touch was reduced in the left limbs. Blood pressure was normal on lying and standing. Results of laboratory findings: WBC count was $6.2 \times 10^{9} / 1$ with a normal differential cell count. Haemoglobin was $9.0 \mathrm{~g} / \mathrm{dl}$. ESR was $84 \mathrm{~mm}$ in one hour. The fasting blood glucose value was $70 \mathrm{mg} / \mathrm{dl}$. The blood level of urea nitrogen and creatinine were $7.3 \mathrm{mmol} / \mathrm{l}$ and $180 \mu \mathrm{mol} / \mathrm{l}$ respectively. Urinalysis revealed a trace of proteinuria. Bence-Jones proteinuria was not found. Serological tests for hepatitis and syphilis were negative. Tests for LE cells, antinuclear antibody, rheumatoid factor and alpha-fetoprotein were negative. Serum protein electrophoresis showed a total protein, $62 \mathrm{~g} / \mathrm{l}$; gammaglobulin, $14.4 \mathrm{~g} / \mathrm{l}$. Radiographs of the chest revealed pleural thickening with blunting of the left costophrenic angle. A plain film of abdomen indicated the presence of moderate amount of ascites. A skeletal survey did not display any lesion. An intravenous pyelogram demonstrated no abnormality. Liver scan suggested hepatosplenomegaly. Pedal lymphangiography showed no significant change of the lymphatic system. Echocardiography demonstrated a dilated left ventricle and pericardial effusion. EEG was

Table 4 Results of nerve stimulation studies

\begin{tabular}{|c|c|c|c|c|c|c|c|c|c|c|c|c|c|c|}
\hline \multirow[t]{3}{*}{ Nerve } & \multicolumn{5}{|c|}{ Distal latency of $M N C(\mathrm{~ms})$} & \multicolumn{5}{|c|}{$M N C V(\mathrm{~m} / \mathrm{s})$} & \multirow{2}{*}{\multicolumn{4}{|c|}{$\frac{S N C V(\mathrm{~m} / \mathrm{s})}{\text { Case }}$}} \\
\hline & \multicolumn{4}{|c|}{ Case } & \multirow[t]{2}{*}{$N R$} & \multicolumn{4}{|l|}{ Case } & \multirow[t]{2}{*}{$N R$} & & & & \\
\hline & 1 & 2 & 3 & 4 & & 1 & 2 & 3 & 4 & & 1 & 2 & 3 & 4 \\
\hline $\begin{array}{c}\text { Median } \\
\text { right } \\
\text { left }\end{array}$ & $4 \cdot 2$ & $\begin{array}{l}4 \cdot 4 \\
3 \cdot 8\end{array}$ & $5 \cdot 3$ & $\begin{array}{l}\mathbf{0} \\
\mathbf{0}\end{array}$ & $2 \cdot 2-4 \cdot 1$ & 37.9 & $\begin{array}{l}43 \cdot 9 \\
32 \cdot 3\end{array}$ & $40 \cdot 2$ & $\begin{array}{l}0 \\
0\end{array}$ & $46 \cdot 9-80 \cdot 8$ & & & & $\begin{array}{l}\mathbf{0} \\
\mathbf{0}\end{array}$ \\
\hline $\begin{array}{c}\text { Ulnar } \\
\text { right } \\
\text { left }\end{array}$ & & $\begin{array}{l}2 \cdot 8 \\
2 \cdot 8\end{array}$ & $4 \cdot 5$ & $\begin{array}{l}0 \\
0\end{array}$ & $1 \cdot 5-3 \cdot 8$ & & $\begin{array}{l}43 \cdot 4 \\
43 \cdot 3\end{array}$ & $36 \cdot 2$ & $\begin{array}{l}0 \\
0 \\
0\end{array}$ & $44 \cdot 2-81 \cdot 7$ & & & & $\begin{array}{l}0 \\
0\end{array}$ \\
\hline $\begin{array}{l}\text { Peroneal } \\
\text { right } \\
\text { left }\end{array}$ & 0 & $\begin{array}{l}4 \cdot 3 \\
4 \cdot 2\end{array}$ & $\begin{array}{l}0 \\
11 \cdot 1\end{array}$ & $\begin{array}{l}0 \\
0 \\
0\end{array}$ & $2 \cdot 8-6 \cdot 4$ & 0 & $\begin{array}{l}40 \cdot 3 \\
39 \cdot 2\end{array}$ & $\begin{array}{l}0 \\
17 \cdot 6\end{array}$ & $\begin{array}{l}0 \\
0 \\
0\end{array}$ & & & $\begin{array}{l}0 \\
33.5\end{array}$ & & $\begin{array}{l}0 \\
0\end{array}$ \\
\hline $\begin{array}{c}\text { Tibial } \\
\text { right } \\
\text { left }\end{array}$ & & $\begin{array}{l}4 \cdot 6 \\
4.8\end{array}$ & $\begin{array}{l}0 \\
0\end{array}$ & $\begin{array}{l}0 \\
0\end{array}$ & $3 \cdot 3-7 \cdot 2$ & & $\begin{array}{l}35 \cdot 4 \\
35 \cdot 0\end{array}$ & $\begin{array}{l}0 \\
0\end{array}$ & $\begin{array}{l}0 \\
0\end{array}$ & $41 \cdot 9-63 \cdot 6$ & & $\begin{array}{l}28 \cdot 8 \\
36 \cdot 1\end{array}$ & & $\begin{array}{l}0 \\
0\end{array}$ \\
\hline
\end{tabular}

MNC: motor nerve conduction

MNCV: motor nerve conduction velocity

SNCV: sensory nerve conduction velocity

NR: normal range

0 : not elicited 


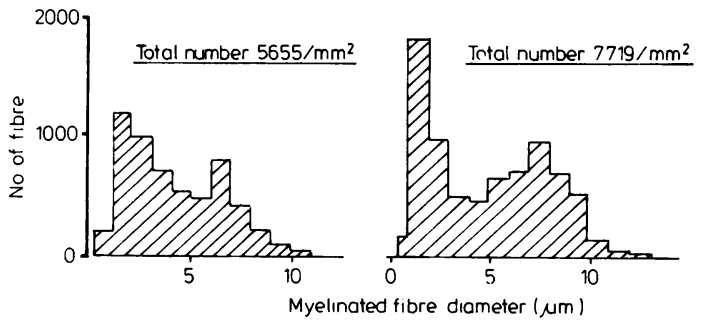

Fig 4 Histograms show fibre spectrum of myelinated nerve fibres of sural nerves in Case 1 (a) and normal control (b).

normal. CT of the head revealed an old infarct in the right occipito-parietal region. Right carotid cerebral angiogram illustrated complete occlusion of the right internal carotid artery at the level of bifurcation. Results of nerve stimulation studies are shown in table 4. EMG was not performed. A CSF examination was normal. Abdominal tapping revealed no malignant cells. Bone marrow biopsy showed slight myeloid hyperplasia, abundant megakaryocytes, increased number of eosinophils and no abnormal cells. Skin biopsy of the nodule showed capillary haemangiomas. Following admission, the patient developed watery diarrhoea. His renal function deteriorated gradually. Peritoneal dialysis was performed three weeks later. Despite the start of therapy with dexamethasone $10 \mathrm{mg}$ daily in late October 1979 , the patient had persistent watery diarrhoea, hyperkalaemia, hypoproteinaemia and uraemia. In late November 1979, the patient developed acute pulmonary oedema and died. Necropsy was not performed.

Case 3, a 48-year-old man developed intermittent oedema of the eyelids and lower legs in January 1979. One month later, he experienced a numb sensation in both feet. In May 1979, he noticed weakness of both legs. In December 1979 , the lower legs were so weak that he could not walk

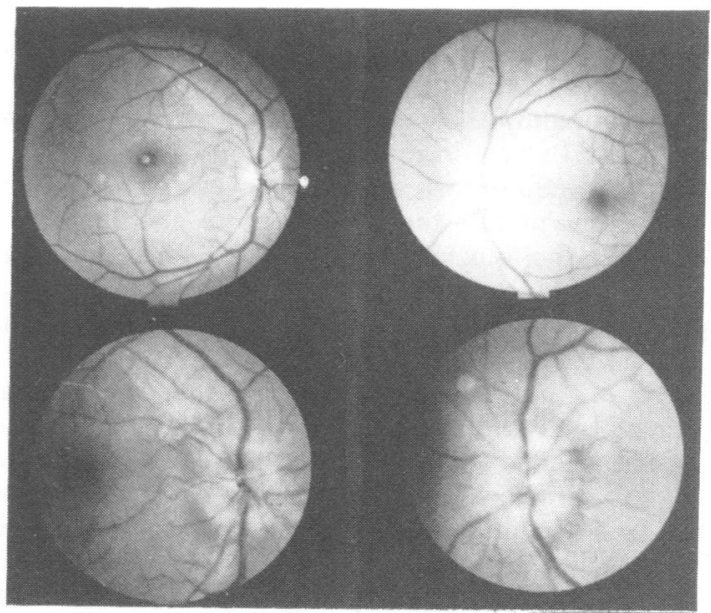

Fig 5 Fundus photographs of Case 1: clear disc margin (top); blurred disc margin (bottom) 14 months later. without support. In January 1980, the patient also developed weakness of the upper extremities. He was admitted in March 1980 for investigation of weakness. The patient's past and family histories were unremarkable. There was no evidence of exposure to toxins or chemicals. Examination revealed diffuse cutaneous hyperpigmentation and gynaecomastia. The fingernails and toenails were whitish. There were multiple pin-head to bean sized reddish papules over palms and trunk. Finger-tip sized lymph nodes were palpable in the neck, axillary and inguinal regions. There was hypertrichosis of both lower legs. The liver was palpable below the costal margin. There was mild weakness of muscle power at shoulders, elbows, wrists and hands. There was marked weakness of power at hips and knees, and severe weakness of power at ankles and toes. Deep tendon reflexes were reduced in the four limbs. There was hypalgesia in the extremities and trunk. There was no sphincter disturbance. Results of investigations: WBC count was $6.1 \times 10^{9} / 1$ with $42 \%$ polymorphonuclear neutrophils, $22 \%$ eosinophils, $5 \%$ mononuclear cells and $31 \%$ lymphocytes. Haemoglobin was $12.7 \mathrm{gm} / \mathrm{dl}$. ESR was $7 \mathrm{~mm}$ in one hour. The fasting blood glucose level was 0.95 $\mathrm{g} / \mathrm{l}$. Blood levels of creatinine and urea nitrogen were 137 $\mu \mathrm{mol} / \mathrm{l}$ and $3 \mathrm{mmol} / \mathrm{l}$ respectively. Urinalysis revealed a trace of proteinuria. Bence-Jones proteinuria was not found. Hookworm eggs were detected by microscopic examination of a concentrated faecal smear. Serological tests for hepatitis and syphilis were negative. Serum protein electrophoresis showed a total protein of $64 \mathrm{~g} / \mathrm{l}$ and gamma-globulin of $13.6 \mathrm{~g} / \mathrm{l}$. Radiographs of the chest and the abdomen were normal. A skeletal survey was negative. Results of nerve stimulation studies are shown in table 4 . EMG of lower extremities revealed fibrillation potentials and positive sharp waves at rest, polyphasic motor unit potentials on minimal effort and markedly decreased interference pattern on maximal effort. EMG of upper extremities showed no abnormality. Bone marrow biopsy revealed $10 \%$ eosinophils and $6 \%$ mature plasma cells. Skin biopsy revealed haemangioma. Following admission, prednisolone $45 \mathrm{mg}$ daily was administered. However, there was no improvement. In late March 1980, the patient was discharged with no change of hyperpigmentation, hypalgesia and power of limbs.

Case 4, 34-year-old man was admitted in April 1981 because of progressive abdominal distension for one year. The patient had been quite well until the spring of 1980 when he experienced impotence, general weakness, loss of appetite and numbness of both legs. In January 1981, the patient noticed numbness of both hands and fore-arms and weakness of lower limbs. In February 1981, he also developed weakness of the upper limbs. There was no remarkable past or family histories. No evidence of exposure to toxins or chemicals was noted. A physical examination revealed diffuse skin hyperpigmentation, whitish fingernails and toenails, and gynaecomastia. There were multiple soft peanut-sized lymph nodes over the neck, axillary and inguinal regions. Hypertrichosis was present over both legs. There was abdominal distension with shifting dullness. The liver was palpable below the costal margin. Lower limb oedema was noted. There was mild weakness of muscle power at shoulders, elbows and hips, marked weakness at wrists and knees, and severe weakness of the 
hands, ankles and toes. Deep tendon reflexes were diminished in the extremities. There were hypalgesia and hypaesthsia in the extremities and trunk. Ophthalmoscopic examination revealed papilloedema. Results of investigations: WBC count was $5.0 \times 10^{9} / 1$ with normal differential cell count. Haemoglobin was $12.3 \mathrm{gm} / \mathrm{dl}$. ESR was $52 \mathrm{~mm}$ in one hour. The fasting blood glucose value was $1 \cdot 1 \mathrm{~g} / \mathrm{l}$. Urinalysis revealed a trace of proteınuria. There was no Bence-Jones proteinuria. Serological tests for hepatitis and syphilis were negative. No M-protein was found. Radiographs of the chest and the abdomen revealed pleural effusion and ascites respectively. A skeletal survey showed no abnormality. Liver-spleen scintiphotographic study suggested hepatosplenomegaly. Bone marrow biopsy yielded $10 \%$ plasma cells. Biopsy of the neck lymph nodes revealed an increased amount of plasma cells. Results of nerve stimulation studies are shown in table 4. EMG of upper extremities showed fibrillation potentials at rest, polyphasic motor unit potentials with long duration on minimal effort and markedly reduced interference pattern on maximal effort. EMG of lower extremities showed no activity at rest or on volition. The patient was treated with prednisolone. However, there was no improvement in the clinical manifestations.

\section{Discussion}

The clinical manifestations of the patients are summarised in table 1 . All patients were male. The mean age was 42.5 years. Their clinical courses were insidious.

The syndrome with involvement of the central and peripheral nervous systems, the skin, the endocrine, the skeleton, and the reticuloendothelial and immuno-haematopoietic systems has been reported in association with plasma cell dyscrasia in the presence or absence of myeloma. This syndrome has been variously named as: (1) multisystemic syndrome by Meshkinpour et al $;^{12}$ (2) POEMS syndrome (polyneuropathy, organomegaly, endocrinopathy, M-protein and skin changes) by Bardwick et $a l,{ }^{13}$ (3) PEP syndrome (polyneuritis, oedema and pigmentation) by Saikawa et al..$^{14}$

The presence of polyneuropathy, pseudotumour cerebri, anasarca and the skin manifestations may suggest a connective tissue disorder. However, this is not supported in the absence of arthritis, arthralgia, rheumatoid factor, LE cells, antinuclear antibody and histological evidence of vasculitis.

In most reported cases with multisystem involvement, either myeloma or M-protein was present. In our series, both myeloma and M-protein were absent. Immunoglobulin values of the four patients are shown in table 2. Results of bone marrow biopsy are shown in table 3 . Since we could not obtain autopsy of the patient who died, we were unable to rule out the possibility that there was a patchy proliferative disorder of the plasma cells in the marrow or extramedullary site.
In our patients, the values of motor nerve conduction velocities and distal latencies of some of the nerves tested are beyond the normal limits for Chinese. ${ }^{15}$ Sensory nerve conduction velocities in two cases were either prolonged or unmeasurable. EMG revealed no bizarre high frequency discharges or giant waves. All the findings suggest the involvement of peripheral nerves rather than the anterior horn cells. The moderate to marked slowing of motor conduction velocities and delay of latencies imply that demyelination is a prominent feature of the neuropathy. Various findings on sural nerve biopsy have been reported.371116 Histological examination of the sural nerve in one of our patients showed neither infiltration of amyloid nor neoplastic cells. There were demyelination and axonal degeneration. The aetiology of the neuropathy was uncertain.

The hearing loss in case 1 was progressive over a period of two weeks which is in contrast to the slowly progressive onset of early presbycusis. The patient presented no history, symptoms or signs of Meniere's syndrome. It is assumed that the sensorineural hearing impairment is one of the manifestations of the syndrome.

There was no excess of CSF protein and no abnormality of brain or of CSF pathways on CT in the two patients with papilloedema. It is suggested that various diseases of the brain, eye and orbit share a final common pathway in disturbance of axoplasmic transport resulting in papilloedema. ${ }^{17}$ It might be that, in our patients, the disease process converged into the pathway of disturbance of axoplasmic transport giving rise to papilloedema.

No risk factors such as hypertension, diabetes mellitus, cardiac impairment, high serum lipid level, high level of haemoglobin or haematocrit, or cigarette smoking were found in the patient who developed cerebral infarction and whether the involvement of the carotid artery is a coincidence or a part of the syndrome is uncertain.

It has been reported that the two most prominent endocrine manifestations are gonadal failure and diabetes mellitus. ${ }^{13}$ In our cases, diabetes mellitus was not detected. The hormonal studies of case 1 and case 4 are shown in table 5 . The increased levels of gonadotropins and prolactin suggest the hypogonadism in our patients was due primarily to gonadal failure rather than to secondarily to the hyperprolactinaemia. Nevertheless, the cause of the hyperprolactinaemia is unknown. There was no evidence of pituitary tumour or hypothalamic disease though microadenoma could not be ruled out. It may be that the hyperprolactinaemia is due to the interruption of dopaminergic impulses impinging on the hypothalamus or the disturbance of the tonic 
Table 5 Hormonal data of two patients

\begin{tabular}{lccl}
\hline & Case 1 & Case 4 & Normal range \\
\hline Tetraiodothyronine & 3.7 & 1.44 & $5.5-14 \mu \mathrm{\mu g} / \mathrm{dl}$ \\
Triiodothyronine & 31.0 & 30.25 & $94-169 \mathrm{ng} / \mathrm{dl}$ \\
T3 resin uptake & 39.6 & 33.8 & $24.2-33.4 \%$ \\
Follicle stimulating & 93.7 & 12.65 & $1-15 \mathrm{mIU} / \mathrm{ml}$ \\
$\quad$ hormone & 19.6 & 24.3 & $1-15 \mathrm{mIU} / \mathrm{ml}$ \\
Luteinising hormone & 42.24 & 80.73 & $0-25 \mathrm{ng} / \mathrm{ml}$ \\
\hline
\end{tabular}

inhibition of prolactin secretion and synthesis from the hypothalamus.

Skin biopsies reported by Bardwick et al ${ }^{13}$ showed an increase in pigmentation of the superficial dermis without any inflammatory cells or proteinaceous infiltration of the deeper structures. Biopsies of skin nodules of two of our patients revealed haemangiomas. No inflammatory cells or malignant cells were seen. Saikawa ${ }^{14}$ suggested that the skin hyperpigmentation might have some connection through melanin stimulating hormone with the secretion of ACTH produced by osteosclerotic tumour; however, plasmacytomas were neither found in our patients nor in cases reported by others. ${ }^{11} 12$

The renal function of the patients were checked during hospitalisation. The values of serum creatinine, urea nitrogen, potassium and the results of the creatinine clearance test are shown in table 6. There was only a trace of proteinuria with neither casts in the urine sediment nor Bence-Jones proteinuria. It is not likely that there is an injurious effect of abnormal protein responsible for the renal function impairment although the cause of the renal involvement is unknown.

One of our patients had non-obstructive ventilatory impairment. This might be the result of changes in the lungs or in the motor system. Nevertheless, there were no findings to suggest that the diminution in lung compliance was secondary to compression of the lung tissue by a space occupying lesion of the lungs or pleura or duffuse changes in the lung parenchyma. We believe therefore that the ventilatory defect was due to a reduction in the maximal force that could be exerted by the respiratory muscles, probably due to impairment of the peripheral nervous system.

Table 6 Results of renal function tests

\begin{tabular}{|c|c|c|c|c|}
\hline & Case 1 & Case 2 & Case 3 & Case 4 \\
\hline $\begin{array}{l}\text { Serum } \\
\text { urea nitrogen }(\mathrm{mmol} / \mathrm{l}) \\
\text { potassium }(\mathrm{mmol} / \mathrm{l}) \\
\text { creatinine }(\mu \mathrm{mol} / \mathrm{l}) \\
\text { Creatinine clearance }\end{array}$ & $\begin{array}{c}2 \cdot 16 \\
4 \cdot 7 \\
94 \cdot 3\end{array}$ & $\begin{array}{r}11.3 \\
6.0 \\
188.5\end{array}$ & $\begin{array}{r}5.3 \\
4.0 \\
175.7\end{array}$ & $\begin{array}{r}9.83 \\
5.0 \\
214.2\end{array}$ \\
\hline test $(\mathrm{ml} / \mathrm{min})$ & 30 & 20 & 12 & 6 \\
\hline
\end{tabular}

The pathogenesis of the syndrome is obscure although various hypotheses have been proposed. In our cases, however, there was no evidence that exposure to toxins or chemicals, production of paraproteins, or neoplasm was responsible for the widespread multisystem involvement.

The authors thank Chung-Yin Chee, MD, for electrophysiological studies.

\section{References}

${ }^{1}$ Scheinker I. Myelom und nerven system: uber une bisher nicht beschriebene mit eigentumlich. Haut veranderungen einhergehende. Polyneuritis bei einem plasma-zellularen myelom der sternums. Dtsch $Z$ Nervenh 1938;147:247-73.

${ }^{2}$ Crow RS. Peripheral neuritis in myelomatosis. $\mathrm{Br}$ Med J 1956;2:802-4.

${ }^{3}$ Aguayo A, Thompson DW, Humphrey JG. Multiple myeloma with polyneuropathy and osteosclerotic lesions. J Neurol Neurosurg Psychiatry 1964;27:562-6.

${ }^{4}$ Davis LE, Drachman DB. Myeloma neuropathy. Successful treatment of two patients and review of cases. Arch Neurol 1972;27:507-11.

${ }^{5}$ Getaz P, Handler L, Jacobs P, Tunley I. Osteosclerotic myeloma with peripheral neuropathy. $S$ Afr Med J 1974;48:1246-50.

- Rohmer F, Mengus M, Buchheit F. Neuropathie paraneoplastique à type de syndrome de Guillain-Barré chez un malade atteint de myelome solitaire. Rev Otoneuroophtalmol 1962;34:97-107.

${ }^{7}$ Read D, Warlow C. Peripheral neuropathy and solitary plasmacytoma. J Neurol Neurosurg Psychiatry 1978;41:177-84.

${ }^{8}$ Shimpo S. Solitary plasmacytoma with polyneuritis and endocrine disturbances. Nippon Rinsho 1968;26:2444-56.

${ }^{9}$ Shimomori T, Kusumoto M. A case of solitary plasmacytoma with polyneuropathy, pigmentation, and gynecomastia (abstract) Nippon Naika Gakkai Zasshi 1970;59:1008.

${ }^{10}$ Iwashita H, Inoue N, Nagamatsu K. Polyneuropathy, pigmentation, diabetes mellitus and monoclonal gammapathy. Report of an autopsy case. Clin Neurol 1971;11:492-9.

$"$ Trentham DE, Masi AT, Marker HW. Polyneuropathy and anasarca: Evidence for a new connective tissue syndrome and vasculopathic contribution. Ann Intern Med 1976;84:271-4.

12 Meshkinpour H, Myung CG, Kramer LS. A unique multisystem syndrome of unknown origin. Arch Intern Med 1977;137:1719-21.

${ }^{13}$ Bardwick PA, Zvaifler NJ, Gill GN, Newman D, Greenway GD, Resnick DL. Plasma cell dyscrasia with polyneuropathy, organomegaly, endocrinopathy, M-protein, and skin changes: The POEMS syndrome. Medicine 1980;59(4):311-22. 
${ }^{14}$ Saikawa S. On the Etiology of "PEP Syndrome (A peculiar Progressive Polyneuritis Associated with Pigmentation, Edema, Plasma Cell Dyscrasia)". Kagoshima University Med J 1980;32:219-320.

is Chen RC, Sung SM, Chen CF, Tzeng CJ, Lien IN, Hung TP. Normal motor nerve conduction velocity amongst Chinese in Taiwan. Taiwan I Hsuch Hui Tsa Chich 1978;77:394-401.
${ }^{16}$ Ohnishi A, Sato Y, Tateishi J, Iwashita H, Kuroiwa Y. Pathology of the peripheral nervous system in a case of osteosclerotic myeloma with polyneuropathy, skin hyperpigmentation, hypertrichosis and edema. Neurol Med 1977;7(6):540-2.

${ }^{17}$ Tso MOM, Hayreh SS. Optic disc edema in raised intracranial pressure. Arch Opthalmol 1977;95:1458-62. 